\title{
The Relations among Lines in the Distribution of $B$ Blood Group Alleles of the Chicken
}

\author{
Yoshihisa FujIo \\ Laboratory of Animal Genetics, Faculty of Agriculture, \\ Nagoya University, Nagoya-shi 464
}

(Received August 7, 1972)

\begin{abstract}
Differences and similarities in the distribution of $\mathrm{B}$ blood group alleles between lines of seven breeds of chicken were estimated by the genetic distance based on a geometrical model. The result indicated that the information on the genetic distance between lines would be useful for the nicking tests. The dendrogram for relations among lines within breed showed the differentiation of lines was caused both by random genetic drift and by directional selection.
\end{abstract}

Previous papers ${ }^{1,2}$, reported that the differences among breeds and their lines were found in the distribution of $\mathrm{B}$ blood group alleles. Therefore, the application of blood grouping enables us to utilize for the characterization of lines in producing commercial chicks and the detection of any contamination that may occur between any of several lines.

There are many informations on the manner in which the $B$ blood group locus exserts its heterotic effect $\mathbf{t}^{\mathbf{3}, 4,6,6,7,8,9)}$. Fuj1 ${ }^{7}$ ) observed that occurrence of heterozygous genotypes was higher than that expected on the basis of Mendelian segregation in the crosses for the B blood group alleles, and demonstrated it to be the result that heterozygotes were superior in hatchability to homozygotes. These heterotic effects would give some interpretation for the combining ability between lines in producing commercial chicks.

In this connection, Fuylo and KONDO1) observed the difference in the distribution of B blood group alleles between lines derived from a flock in which the reciprocal recurrent selection had been carried out, and suggested that the difference was to produce the desireble combination of alleles at the $B$ blood group locus. Thus, it would be necessary to estimate numerically the differences and similarities between lines.

In the present work, the genetic distances based on a geometrical model between lines of seven breeds were calculated and the differences and similarities between them were discussed from genetic point of view.

\section{Materials and Methods}

Lists on gene frequencies at the B blood group locus in the chicken were given in the previous papersi,2). The breeds dealt with in the work were White Leghorn (WL), Barred Plymouth Rock (BPR), Rhode Island Red (RIR), New Hampshire (NH), Nagoya (NG), White Plymouth Rock (WPR), and White Cornish (WC).

In order to investigate the relations among lines, the genetic distance was calculated on the basis of gene frequency. As described in the previous papers, when negative birds 


\section{Genetic Distances among Lines of Chicken}

against the five antisera (this phenotype was indicated 0 ) existed, the frequency was estimated by Bernstein's improved method and the gene was designated as $B^{0}$ gene. Bernstein's improved method may have some error because a relative advantage of heterozygotes existed. However, the error was thought to be small for the investigation of relations.

For the the calculation of genetic distance, the following formula was employed. The genetic distance between two lines $\left(j\right.$ and $k$ ) in an 6 -allelic-dimensional space, $D_{j k}$, is

$$
D_{j k}=\left[\frac{\sum_{i=1}^{n}\left(X_{i j}-X_{i k}\right)^{2}}{2}\right]^{1 / 2}
$$

$X_{i j}$ and $X_{i k}$ represent the frequencies of $i$ allele in lines $j$ and $k$, respectively. This method of calculating genetic distance was given by SoKaL and SNEATH ${ }^{10)}$, and the author extended the use of the formula to gene frequency data.

Dendrogram expressing relative similarities among lines was drawn with an average distance between branches calculated by the weighted pair-group method ${ }^{10}$.

\section{Results}

The matrix of distances between lines in WL are shown in Table 1 . If the two lines are identical in regard to gene frequencies at the B blood group locus, the distance between them will be zero. The larger the difference between them, the larger will be the distance. The maximum distance possible between lines would be 1 . For example, the smallest distances were obtained between WL 10 and WL 12, between WL 10 and WL 14, and between WL 12 and WL 14, that is, the values were $0.030,0.039$, and 0.008 , respectively. These lines were composed of both $B^{A}$ and $B^{M}$ genes and their frequencies were similar to each other. Remarkably small distance value was also obtained between WL 1 and WL 4 . These lines possessed two genes $B^{A}$ and $B^{G}$ and showed the presence of 0 type birds. Frequencies of $B^{A}$ and $B^{G}$ were similar to each other. On the other hand, the largest distance was obtained between WL 17 and WL 24, that is, the value was 0.810 . In the gene constitution, WL 17 was significantly different from WL 24 , that is, the former possessed $B^{A}$ and $B^{M}$ genes and the latter $B^{G}$ and $B^{K}$ genes.

The practice of nicking test in producing commercial chicks would be quite compatible with the results of distance estimation. Both lines WL 4 and WL 5 are descendants of a line and reciprocal recurrent selection was carried out between them. Pair of lines WL 21 and WL 24 also has the same situation. The distance values between WL 4 and WL 5 and between WL 21 and WL 24 were relatively large, that is, 0.368 and 0.632 , respectively. The distances between pairs of lines which are used practically in the four way crosses for the production of commercial chicks are of interest. WL 4, WL 5, WL 9 and WL 10 were an example and WL 16, WL 17, WL 18 and WL 19 were another (Fig. 1). The distances between WL 4 and WL 9 , between WL 4 and WL 10, between WL 5 and WL 9 , and between WL 5 and WL 10 were larger than those between WL 4 and WL 5 and between WL 9 and WL 10. It indicated that there was a large distance between mother lines and father lines. The similar relationship was observed in the latter example.

To summarize the relations among lines within breed, the dendrograms were drawn on the basis of similarity illustrated with an average distance. These are presented in Figs. 2, 3 , and 4. Vertical line was drawn across the dendrograms as an attempt to delimit group at 
Fujo

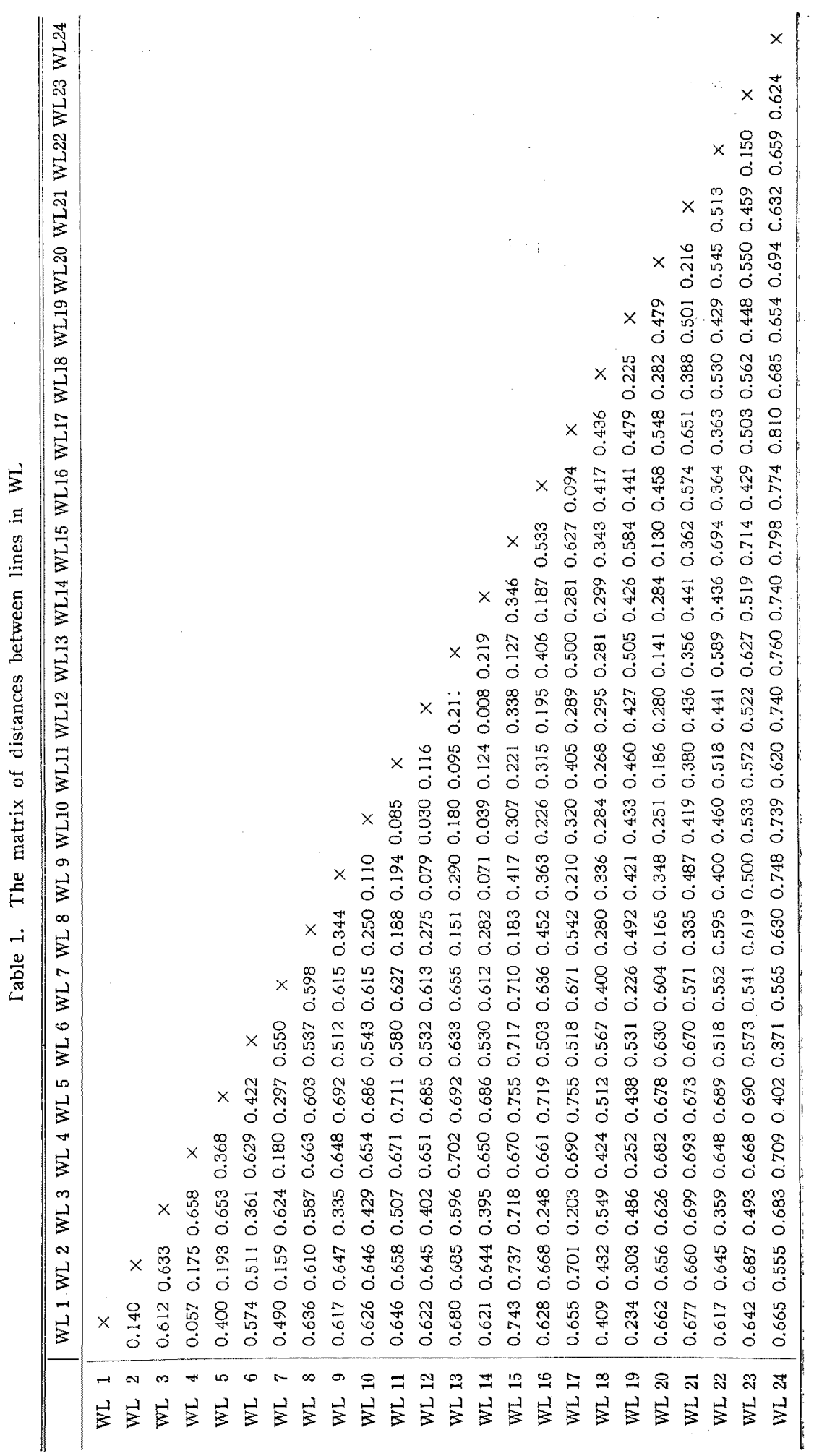


Genetic Distances among Lines of Chicken

I)

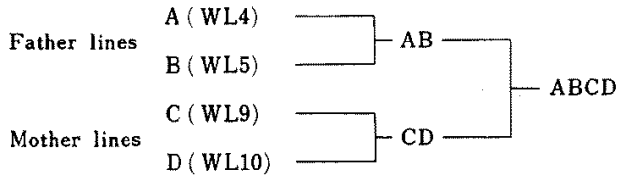

II)

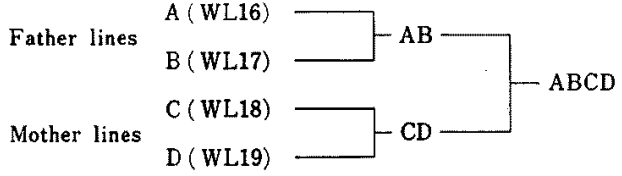

Fig. 1. Four way crosses for production of commercial chicks

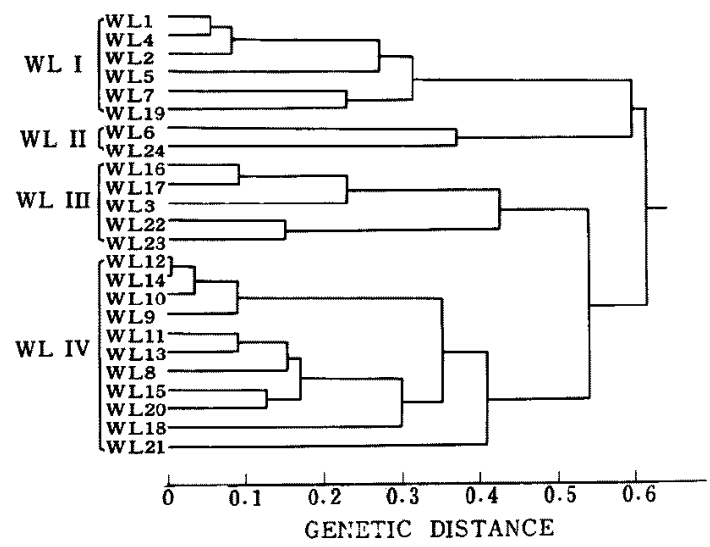

Fig. 2. The dendrogram of relations among lines in WL

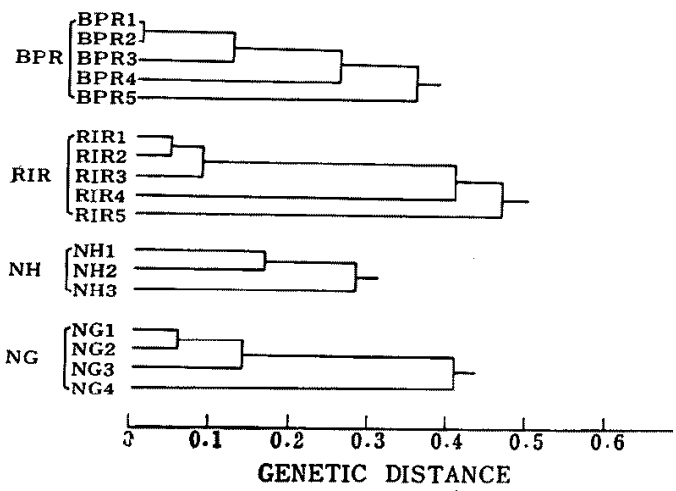

Fig. 3. The dendrogram of relations among lines in BPR, RIR, NH, and NG. 


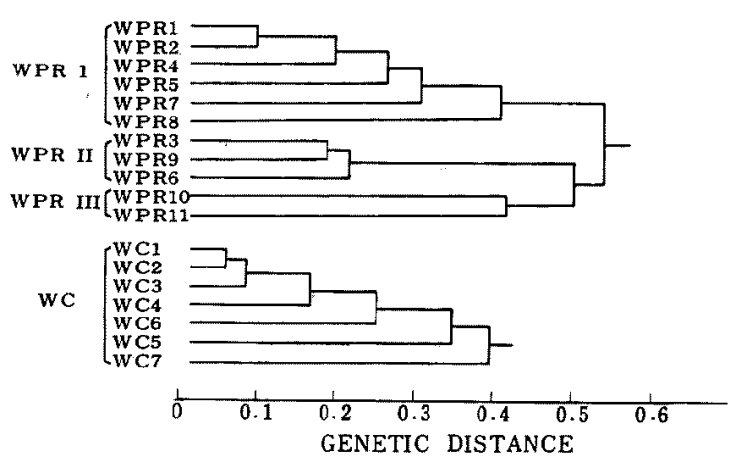

Fig. 4. The dendrogram of relations among lines in WPR and WC

Table 2. Mean gene frequencies at the $B$ blood group locus in seven breeds

\begin{tabular}{|c|c|c|c|c|c|c|c|}
\hline \multirow{2}{*}{ Breed } & \multirow{2}{*}{$\begin{array}{l}\text { No. of lines } \\
\text { tested }\end{array}$} & \multicolumn{6}{|c|}{ Allele } \\
\hline & & $q_{A}$ & $q_{B}$ & $q_{G}$ & $q_{K}$ & $q_{M}$ & $q_{0}$ \\
\hline WL I & 6 & $\begin{array}{l}16.6 \\
(6 / 6) *\end{array}$ & $\begin{array}{c}0.0 \\
(0 / 6)\end{array}$ & $\begin{array}{l}20.3 \\
(5 / 6)\end{array}$ & $\begin{array}{c}4.7 \\
(2 / 6)\end{array}$ & $\begin{array}{c}2.0 \\
(1 / 6)\end{array}$ & $\begin{array}{l}56.7 \\
(6 / 6)\end{array}$ \\
\hline W L II & 2 & $\begin{array}{l}20.9 \\
(1 / 2)\end{array}$ & $\begin{array}{c}0.0 \\
(0 / 2)\end{array}$ & $\begin{array}{l}64.3 \\
(2 / 2)\end{array}$ & $\begin{array}{l}14.2 \\
(1 / 2)\end{array}$ & $\begin{array}{c}0.0 \\
(0 / 2)\end{array}$ & $\begin{array}{c}0.0 \\
(0 / 2)\end{array}$ \\
\hline WL III & 5 & $\begin{array}{l}67.2 \\
(5 / 5)\end{array}$ & $\begin{array}{l}0.0 \\
(0 / 5)\end{array}$ & $\begin{array}{c}4.4 \\
(1 / 5)\end{array}$ & $\begin{array}{l}19.6 \\
(2 / 5)\end{array}$ & $\begin{array}{c}8.9 \\
(2 / 5)\end{array}$ & $\begin{array}{c}0.0 \\
(0 / 5)\end{array}$ \\
\hline W L IV & 11 & $\begin{array}{l}35.5 \\
(11 / 11)\end{array}$ & $\begin{array}{l}0.0 \\
(0 / 11)\end{array}$ & $\begin{array}{l}1.5 \\
(1 / 11)\end{array}$ & $\begin{array}{l}5.1 \\
(2 / 11)\end{array}$ & $\begin{array}{c}54.9 \\
(11 / 11)\end{array}$ & $\begin{array}{c}2.8 \\
(1 / 11)\end{array}$ \\
\hline BPR & 5 & $\begin{array}{l}13.6 \\
(4 / 5)\end{array}$ & $\begin{array}{c}8.0 \\
(1 / 5)\end{array}$ & $\begin{array}{l}48.4 \\
(5 / 5)\end{array}$ & $\begin{array}{l}22.7 \\
(4 / 5)\end{array}$ & $\begin{array}{c}4.5 \\
(1 / 5)\end{array}$ & $\begin{array}{c}2.3 \\
(1 / 5)\end{array}$ \\
\hline R I R & 5 & $\begin{array}{l}11.0 \\
(2 / 5)\end{array}$ & $\begin{array}{l}1.6 \\
(1 / 5)\end{array}$ & $\begin{array}{l}46.4 \\
(5 / 5)\end{array}$ & $\begin{array}{l}39.2 \\
(5 / 5)\end{array}$ & $\begin{array}{c}1.7 \\
(1 / 5)\end{array}$ & $\begin{array}{c}0.0 \\
(0 / 5)\end{array}$ \\
\hline $\mathrm{NH}$ & 3 & $\begin{array}{c}0.0 \\
(0 / 3)\end{array}$ & $\begin{array}{c}0.0 \\
(0 / 3)\end{array}$ & $\begin{array}{l}41.8 \\
(3 / 3)\end{array}$ & $\begin{array}{l}14.7 \\
(2 / 3)\end{array}$ & $\begin{array}{c}0.0 \\
(0 / 3)\end{array}$ & $\begin{array}{l}43.2 \\
(3 / 3)\end{array}$ \\
\hline NG & 4 & $\begin{array}{c}0.0 \\
(0 / 4)\end{array}$ & $\begin{array}{l}51.2 \\
(4 / 4)\end{array}$ & $\begin{array}{l}48.6 \\
(4 / 4)\end{array}$ & $\begin{array}{c}0.0 \\
(0 / 4)\end{array}$ & $\begin{array}{c}0.0 \\
(0 / 4)\end{array}$ & $\begin{array}{c}0.0 \\
(0 / 4)\end{array}$ \\
\hline WPR I & 6 & $\begin{array}{c}6.1 \\
(1 / 6)\end{array}$ & $\begin{array}{c}0.0 \\
(0 / 6)\end{array}$ & $\begin{array}{l}32.7 \\
(6 / 6)\end{array}$ & $\begin{array}{c}3.7 \\
(2 / 6)\end{array}$ & $\begin{array}{l}34.1 \\
(6 / 6)\end{array}$ & $\begin{array}{l}22.9 \\
(4 / 6)\end{array}$ \\
\hline WPR II & 3 & $\begin{array}{l}1.6 \\
(1 / 3)\end{array}$ & $\begin{array}{l}5.0 \\
(1 / 3)\end{array}$ & $\begin{array}{l}12.5 \\
(2 / 3)\end{array}$ & $\begin{array}{c}7.9 \\
(1 / 3)\end{array}$ & $\begin{array}{c}6.5 \\
(2 / 3)\end{array}$ & $\begin{array}{l}66.0 \\
(3 / 3)\end{array}$ \\
\hline WPR III & 2 & $\begin{array}{l}23.5 \\
(1 / 2)\end{array}$ & $\begin{array}{l}41.8 \\
(2 / 2)\end{array}$ & $\begin{array}{c}0.0 \\
(0 / 2)\end{array}$ & $\begin{array}{c}0.0 \\
(0 / 2)\end{array}$ & $\begin{array}{l}9.1 \\
(1 / 2)\end{array}$ & $\begin{array}{l}23.2 \\
(2 / 2)\end{array}$ \\
\hline $\mathrm{WC}$ & 7 & $\begin{array}{c}5.1 \\
(1 / 7)\end{array}$ & $\begin{array}{c}3.2 \\
(1 / 7)\end{array}$ & $\begin{array}{l}21.1 \\
(6 / 7)\end{array}$ & $\begin{array}{c}2.0 \\
(1 / 7)\end{array}$ & $\begin{array}{l}22.2 \\
(7 / 7)\end{array}$ & $\begin{array}{l}46.1 \\
(7 / 7)\end{array}$ \\
\hline
\end{tabular}

* The numerator represents the number of lines possessed allele and the denominator represents the number of lines tested.

the level showing 50 percent of similarity (at 0.5 of distance). The dendrogram of NG which was derived from a flock was present at the level (Fig. 3). Using this vertical line, 24 lines of WL are divided into four groups as shown in Fig. 2, that is, (WL 1-WL 19), (WL 6-WL 24), (WL 16-WL 23), and (WL 12-WL 21). Eleven lines of WPR are also divided into three groups as shown in Fig. 4, that is, (WPR 1-WPR 8), (WPR 3-WPR 6), and (WPR 10-WPR 11). The grouping indicates the differentiation of lines in a breed, 


\section{Genetic Distances among Lines of Chicken}

assuming no line arising from hybridization between breeds nor lines. On the other hand, the differentiation of lines was not observed in BPR, RIR, NH, NG, and WC (Figs. 3 and 4).

The differences in gene constitution between groups were shown in Table 2. In four groups of WL, the first group possessed $B^{A}$ and $B^{G}$ genes commonly and the frequency of 0 type was remarkably high. The second group possessed only $B^{G}$ gene commonly and its frequency was high. The third group possessed only $B^{A}$ gene commonly with high frequency, and the last group possessed two genes, $B^{A}$ and $B^{M}$, commonly. In three groups of WPR, the first group possessed relatively many $B^{G}$ and $B^{M}$ genes and showed the presence of 0 type birds. The second group showed a similar gene distribution as the first group but 0 type was dominated. The last group showed a different gene constitution from the former two groups, that is, the frequency of $B^{B}$ gene was high.

\section{Discussion}

The present work showed that in the $B$ blood group system the distance between two lines, with which the reciprocal recurrent selection had been carried out, was relatively great. Furthermore, large distance between mother lines and father lines used practically for the production of commercial chicks was shown. It suggests that the larger the distance between two lines, the greater will be the anticipation of heterosis. There are many evidences that heterozygotes of the $B$ blood group locus were superior to homozygotes in fertility, hatchability, viability, and egg production. The heterotic effect would give some interpretation for the combining ability of both lines in producing commercial chicks. Here is an information on only the $B$ blood group locus, but clearly the precision of the answer will increase with number of loci which have heterotic effects. In this connection, there are some informations on the other blood group loci having heterotic effects. Higher fitness of heterozygote at the A blood group locus was reported by SHuLTz and BrILEs ${ }^{11)}$. SeEt and BriLes ${ }^{12)}$ also reported that hatchability of eggs fertilized by the heterozygous sires for the A blood group locus was significantly higher than for the homozygous sires. DESilva ${ }^{13}$ ) found for the $L$ blood group locus the lowest fertility in the homozygous $X$ homozygous matings and demonstrated an advantage of heterozygosis in either parent for fertility.

The dendrogram indicated the differentiation of lines within breed. It was assumed that the differentiation of lines or genetic diversity among lines has been caused by both random genetic drift and directional selection. If the differentiation of lines has been caused only by random genetic drift, the dendrogram would give a evolutionary tree expressing differentiation of lines by random process. However, there are informations on association between $B$ blood group antigens and such performance traits of economic importance as fertility, hatchability, viability, resistance to leucosis, and egg production ${ }^{6,12,14,15,16,17,18}$. Then, the differentiation of lines might also be caused by directional selection associated with these performance traits.

The author wishes to express his hearty thanks to Dr. K. NozAwA of the Primate Research Institute of Kyoto University for reading the manuscript and offering his valuable suggestions. The author also thanks to Prof. K. Konbo for his advice and encouragements. 


\section{References}

1) Fujio, Y., and K. Kondo, Jap J Zootech Sci 41: 593-600. 1970.

2) Natsume, N., Y. Fujio, and K. Kondo, Jap J Zootech Sci 43: 712-718. 1972.

3) AlLeN, C.P., and D.G. Grlmour, Genetics 47: 1711-1718. 1962.

4) Briles, W.E., and W.F. Krueger, Poultry Sci 34: 1182. 1955.

5) Briles, W.E., C.P. Allen, and T.W. Millen, Genetics 42: 631-648. 1957.

6) Briles, W.E., and C.P. Allen, Genetics 46: 1273-1293. 1961.

7) Fujto, Y., Jap J Genet 46: 181-189. 1971.

8) Morton, J.R., D.G. Gilmour, E.M. McDermid, and A.L. Ogden, Genetics 51 : 97-107. 1965.

9) ОкарA, I., and K. Мatsumoto, Jap J Genet 37: 267-275. 1962.

10) Sokal, R.R., and P.H.A. Sneath, Principles of Numerical Taxonomy 1st ed. 143-151, 305312. W.H. Freeman and Co. San Francisco and London. 1963.

11) Shultz, F.T., and W.E. Briles, Genetics 38: 34-50. 1953.

12) SeET, C.P., and C.O. Briles, Poultry Sci 49: 922-926. 1970.

13) DeSilva, P.L.G., Genetics 51: 41-48. 1965.

14) Allen, C.P., Ann NY Acad Sci 97: 184-193. 1962.

15) Grlmour, D.G., Brit Poultry Sci 1: 75-100. 1960.

16) McDermid, E.M., Proc of the Xth Eur Conf on Animal Blood Groups and Biochemical Polymorphism 223-230. Paris. 1966.

17) Nishimura, I., K. Kamata, M. Hasegawa, and Y. Fujto, Jap J Zootech Sci 42 (Suppl.): 105. 1971.

18) Okada, I., T. Hasegawa, S. Sekidera, H. Shimizu, and Y. Hachinohe, Jap J Zootech Sci 37: 302-311. 1966.

\section{ニワトリの系統間の遺伝的類似関係}

\section{藤 尾芳 久}

名古屋大学農学部, 名古屋市 464

\begin{abstract}
品種および系統におけるB血液型の分布について前 2 報で報告した．これらのデータをむとにして品種内の采 統間の遺伝的類似関係安数量分類学の手法定用いて推定 した. WL 24 柔統, BPR 5 系統, RIR 5 柔統, NH 3 系 統, NG 4 采統, WPR 11 系統, WC 7 系統のB血液型 遺伝子頻度を用い，采統間の類似度を推定するために各

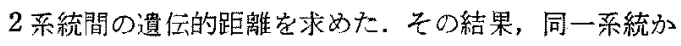
ら分けられ，楖反復選抜が沶こなるれれた 2 系統間の遺
\end{abstract}

伝的距離は大きかった。またコマーシャルチック生産 に用いられている父系と母系との間の遺伝的距離む大き かった。このことは，遺伝的距離を求めることにより実 際に組合わせ検定を扔こなわずに組合せ能力をある程度 推定しうることを示唆している，枝分かれ図から WL は 4 ダルーブ，WPR は 3 グループに分けられた. この ことは品種内の系統の分化を示している。一方，BPR, RIR, NH, NG, WC では采統の分化が著しくなかった 